\title{
STRATEGI KOMUNIKASI PEMASARAN OPPO BENGKULU "Studi Deskriptif TSPV dalam Berkomunikasi dengan Promotor OPPO Cabang Bengkulu"
}

Oleh:

\section{PUTRI NING RAHAYU}

\author{
Magister Ilmu Komunikasi Universitas Bengkulu
}

\begin{abstract}
Marketing Communication is a form of strategy intended to improve the quality of the company and the limited company's goals. In addition, marketing communication activities are activities that are designed to create structured management and reach the quality of work in company. The research was conducted to find out how the Marketing Communication Strategy for marketing activities in the OPPO Bengkulu Company. The object of this study was carried out to study marketing strategies in marketing activities at the OPPO Bengkulu company. While the research subjects were the OPPO Bengkulu Company which was stationed in Bengkulu and chosen by this company because of its position as TSPV manager in the field of discussing and improving the quality of the company (promoter). The theory used in this research is the theory of Internal Communication according to Lawrence D. Brennan which supports two things, namely vertical and horizontal communication. The research has revealed the marketing process itself by establishing a feed on activities as well as the marketing process. The results showed that team management and knowledge control were very important in increasing sales and customer satisfaction found in the case study. Based on the analysis, it is concluded that the marketing communication strategy of OPPO Bengkulu company uses the activities of the TSPV management team consisting of training products, follow-up, persuasive communication and impact management. Many marketing activities are supported by TSPV team activities towards promoters (employees) in increasing sales figures.
\end{abstract}

Keywords : strategy, marketing communication, marketing activities.

\section{PENDAHULUAN}

Dalam dunia marketing "Target" adalah sebuah momok yang memang wajib dikejar oleh setiap pihak agar mengetahui acuan dari pekerjaan marketingnya ini akan seperti apa dan bagaimana. Proses pembagian target tidak hanya dari angka saja melainkan juga dari Target user yang akan ditawarkan produk. Target user juga harus dipikirkan secara matang, mulai dari persiapan alat-alat untuk berkomunikasi dan menunjang penjelasan saat berjualan, kondisi, situasi dan juga rekomendasi yang sesuai dengan kebutuhan user. Hal ini lah yang kemudian menjadi acuan seorang sales dalam bertindak. Sehingga tindakan yang tidak berdasarkan asas 'asal jadi' atau kedekatan saja. Karena dalam dunia Marketing dikenal Rumusan 6-3-1 yaitu $60 \%$ Agresif $30 \%$ Knowledge dan $10 \%$ Keberuntungan. Disini terlihat bahwa keberuntungan hanya akan mempengaruhi sedikit sekali. Berarti harus ada sebuah acuan target sebagai pedoman dalam melakukan sebuah aktivitas penunjang. 
OPPO Bengkulu merupakan perusahaan marketing cabang dari pusat Jakarta yang dibawahi langsung dari negara yang membawa merk ini yaitu China. Perusahaan OPPO Bengkulu bermula di awal tahun 2013 dan saat itu perusahaan ini hanya memiliki sedikit sekali karyawan baik dari staff ataupun sales yang dimilikinya. Hingga akhirnya perkembangan OPPO Bengkulu terus pesat karena hal yang dianggap beberapa rekan kerja bisnis bahwa perusahaan ini mampu memberikan kenyamanan dan penjualan yang sangat baik. OPPO hadir dengan smartphone yang bertajuk selfie expert hingga mulai banyak kompetitor yang melakukan hal yang sama dengan teknologinya. OPPO Bengkulu juga memberikan kenyamanan kepada user dengan mendirikan 2 unit service center di Areanya yaitu Kota Bengkulu dan Lubuk Linggau. Dimana area Lubuk Linggau masuk ke dalam region Bengkulu. Hal ini dikarenakan pimpinan OPPO Indonesia menganggap jarak Bengkulu dan Linggau jauh lebih dekat sehingga masuklah kedalam Big Bengkulu.

Kemudian OPPO Big Bengkulu memiliki 1 RGM (Region Genderal Manager) yang bertanggung jawab atas cabang ini secara fokus kepada OPPO, lalu diikuti RM (Region Manager) yang memegang area yang dibagi jauh lebih kecil lagi. Baru kemudian diikuti oleh beberapa divisi leader yang bergaris langsung dengan pimpinan besar tersebut. Dengan urutan terbawahnya baru akan terhubung kepada promotor. Dimana promotor memiliki sosok tutor yang menjadi orang tua bagi mereka yang akan memberikan monitoring dan dewan guru yaitu trainer yang bertanggung jawab akan knowledge SDM perusahaan. Pihak yang menjual dan memperkenalkan produk kepada user dan berada pada toko-toko yang sudah disesuaikan oleh bos areanya masing-masing.

Promotor biasanya berada pada toko yang memiliki grade per masing-masing area. Disini peran trainer dan tutor saling berkesinambungan dalam membuat keputusan bahwa promotor tersebut sesuai di toko itu atau bukan. Penyesuaian ini tetap akan melewati sales dan SPV sebagai pemilik area namun trainer dan tutor berperan menjadi seperti pemberi nasehat dan penawaran orang tua kepada pihak yang bersangkutan. Promotor dalam perusahaan OPPO Bengkulu melakukan aktivitas seperti promosi, penjualan produk dan masih banyak aktfitas lainnya. Setiap promotor mendapatkan target penjualan dan wajib mengetahui produk bahkan menguasai switching product serta penanganan bila ada komplain dari user (konsumen).

Perbedaan yang terjadi antara divisi lain ialah trainer dan tutor ini di awasi tidak hanya oleh area melainkan oleh tim pusat atau lebih di kenal dengan HQ. Team ini tidak hanya sekedar mengurusi bagaiman promotor memberikan peningkatan penjualan tapi bagaimana kemudian peneliti melihat hasil yang dilakukan untuk kemudian berdampak dengan peningkatan penjualan. Dalam bahasan Komunikasi Organisasi oleh Kanter (1976), menjelaskan bahwa adanya proses seperti penghargaan diri, aspirasi komitmen, energi dan menjadi pemecahan masalah dalam pekerjaan promotor. Peran memonitoring kegiatan pekerjaan promotor adalah sikap follow up dari tim trainer dan tutor yang memastikan semua hal yang berhubungan dengan penjualan dan promotor berjalan dengan baik. Meningkatnya tingkat turn over maka kualitas promotor wajib ditingkatkan lebih dari sebelumnya.

Persyaratan memiliki promotor juga beragam sesuai dengan kemampuan dan kerjasama yang dijalin antara OPPO dan toko. Penjualan ini juga didukung dengan kemauan serta dukungan toko untuk push penjualan produk kepada user. Namun disini baiknya hubungan dengan pihak toko juga disambungkan dengan kemampuan promotor. Layaknya seorang pekerja yang memiliki karyawan dan kantor. Maka kantor bagi promotor adalah 
toko itu sendiri. Berdasarkan latar belakang yang dijelaskan di atas maka penelitian ini akan membahas mengenai beberapa hal sebagai berikut : Bagaimana strategi komunikasi yang dilakukan oleh TSPV dalam meningkatkan kemampuan berjualan di Perusahaan OPPO Bengkulu?

\section{METODE PENELITIAN}

Metode yang digunakan dalam penelitian ini ialah kualitatif dengan proses identifikasi sehingga membuat pemaparan terhadap penelitian lebih mendalam. Proses mengolah juga jauh lebih baik sehingga informan pun menjadi nyaman dalam proses penelitian. Penelitian ini mengambil dasar penjelasan kualitatif sehingga mampu lebih menjabarkan lebih terperinci siklus strategi yang dilakukan oleh perusahaan OPPO untuk mempertahankan posisi terbaiknya dan menjaga waktu pemaparan lebih baik. Pada penelitian ini peneliti membuat semua informan adalah informan utama dikarenakan pada penelitian ini semua informan merupakan orang-orang yang terlibat dalam interaksi. Proses komunikasi yang dijalani oleh informan utama ialah situasi dimana individu atau kelompok tersebut terlibat langsung ke dalam interaksi yang dilakukan. Promotor yang merupakan sumber daya manusia yang dianggap mampu memberikan peningkatan dengan bantuan atau hasil analisa berdasarkan strategi pemasaran untuk meningkatkan penjualan hanya dalam kurun waktu yang cukup singkat ditengat ketatnya persaingan kompetitor yang sangat banyak sekali.

\section{Pengumpulan Data}

Pengumpulan data dalam penelitian ini dengan cara melakukan observasi, wawancara dengan key informant serta studi dokumentasi. Data penelitian hasil wawancara dicatat dan direkam selalui teknik pengamatan langsung dan wawancara mendalam. Dokumentasi juga digunakan sebagai teknik pengumpulan data penunjang. Wawancara banyak dilakukan dalam posisi informan berada di institusinya untuk memperoleh data-data tentang strategi komunikasi pemasaran yang dilaksanakan perusahaan.

Hasil pengamatan dan wawancara yang diperoleh dari key informant kemudian dikumpulkan dan setelah dilakukan reduksi data. Reduksi data merupakan pemilihan data yang relevan dengan masalah penelitian dan dilakukan secara terus - menerus selama proses penelitian berlangsung. Pada tahapan ini setelah data di pilah kemudian disederhanakan data yang tidak diperlukan disunting agar memberi kemudian dalam penampilan, penyajian serta kesimpulan sementara.

Dalam proses analisis data, ketiga tahapan di atas yaitu reduksi data, penyajian data dan verifikasi berlangsung secara bersamaan dengan proses pengumpulan data. Setelah selesai melakukan penyajian data, penarikan kesimpulan dilakukan sebagai suatu kegiatan dari konfigurasi yang utuh.

\section{Triangulasi}

Dari sumber yang dibaca oleh peneliti ialah diketahui bahwa teknik pengumpulan data selain yang di share sebelumnya bahwa memerlukan triangulasi yang sesungguhnya memiliki fungsi baik dalam sebuah penelitian. Triangulasi pada hakikatnya merupakan pendekatan multi metode yang dilakukan peneliti pada saat mengumpulkan dan menganalisis data. Ide dasarnya adalah bahwa fenomena yang diteliti dapat dipahami dengan baik sehingga diperoleh kebenaran tingkat tinggi jika didekati dari berbagai sudut pandang.

\section{Kerangka Pemikiran}

Peran promotor saat bersentuhan dengan konsumen memberikan peningkatan atau peluang jual jauh lebih banyak. Menjadikan promotor sebagai tokoh utama yang harus digembleng 
dengan baik. Manajemen tersendiri yang bertugas dan bertanggung jawab atas hal pengetahuan, kemampuan, semangat kerja, dan pendekatan persuasif dibuat untuk membangun dan mempertahankan penjualan di pasar yang ramai. Sentuhan promotor terhadap owner adalah bentuk komunikasi lainnya yang ada di dalam toko saat promotor push penjualan disana. Atas hal tersebut maka Kerangka pemikiran ini dimuat.

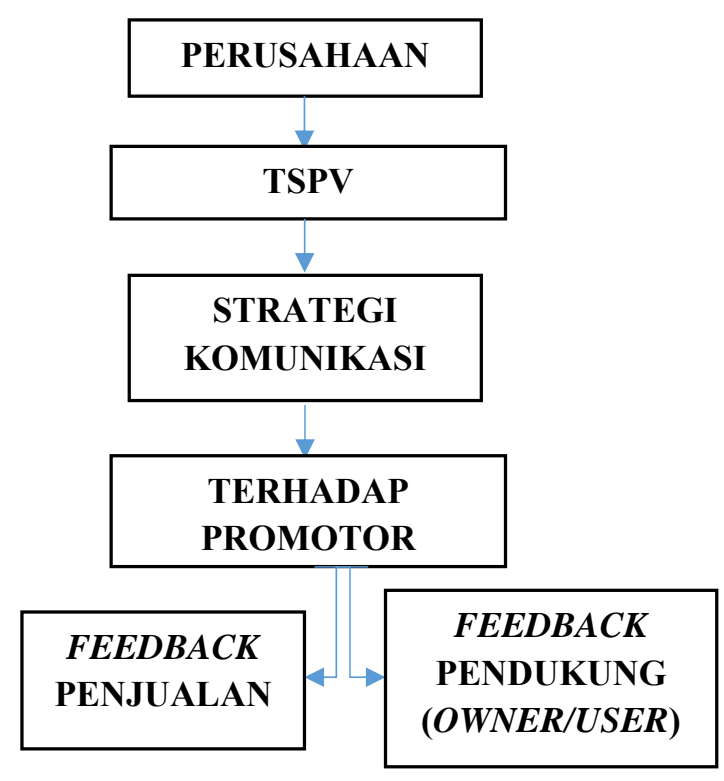

Gambar 1. Kerangka Pikir Penelitian (Sumber: Peneliti)

\section{HASIL DAN PEMBAHASAN}

Berdasarkan hasil obervasi, wawancara mendalam, observasi lapangan dan analisis terhadap strategi komunikasi pemasaran pada perusahaan OPPO Bengkulu dapat dikemukakan dalam membangun komunikasi pemasarannya perusahaan menggunakan bentuk komunikasi pemasaran seperti training product, follow up, komunikasi persuasif dan dampak managemen. Dari berbagai bentuk komunikasi pemasaran yang digunakan, ternyata follow up hasil yang dilakukan oleh tim TSPV dalam memanage promotor dinilai mampu meningkatkan penjualan dengan membentuk kemampuan promotor. Secara lebih lengkap, hasil penelitian penulis paparkan berikut ini :

\section{Management Trainer dan Tutor; Perubahan TSPV}

Model AIDA (Attention, Interest, Desire, Action) adalah salah satu model hirarki respon yang cukup popular bagi pemasar sebagai pedoman dalam melaksanakan kegiatan pemasaran. Menurut model ini, alat promosi harus menarik perhatian, mendapatkan dan mendorong minat, membangkitkan keinginan, dan menghasilkan tindakan. Menurut Belch dalam membangun program komunikasi yang efektif, aspek terpenting adalah memahami proses terjadinya respon dari konsumen, misalnya dalam hal konsumen melakukan pembelian suatu produk, maka diperlukan pemahaman mengenai usaha promosi yang dapat mempengaruhi respon konsumen tersebut (Nurbenny, 2005: 38). Maka berdasarkan hasil penelitian ini peneliti melihat proses komunikasi dan cara follow up yang dilakukan oleh tim TSPV dalam memanage promotor sehingga mampu meningkatkan penjualan dengan membentuk kemampuan promotor.

Sebelumnya telah dijelaskan mengenai Training Product, maka salah satu bentuknya dengan training baik secara soft skill atau untuk hard skill_nya. Dalam model ini akan dilihat kegiatan pemasarannya dengan proses komunikasi yang dijalankan oleh divisi TSPV sehingga menghasilkan user yang percaya dengan kemampuan dan manfaat dari marketing yang dilakukan. Berdasarkan dengan judul penelitian dalam proses peningkatan untuk mengembangkan kualitas promotor menilik dari metode yang digunakan maka pengujian nya ialah :

Attention, dalam proses ini promotor akan membentuk dan diberikan pelatihan mengenai sikap dan cara mengimplementasikan kegiatan dalam menarik perhatian user. 
Penarik perhatian dalam dunia marketing tidak hanya dari yang di display namun juga ada seperti informasi tambahan lainnya seperti program bundling atau lainnya. Mengetahui hal ditengah masa pandemi ini juga promotor diberikan link online dengan whatsApp dan memiliki akun tersendiri untuk memudahkan penjualan meskipun tidak secara langsung. Praktik cara penjualan online juga di kontrol oleh tim TSPV untuk memastikan efektivitas dari iklan tersebut.

Interest, membangun rasa kecintaan terhadap produk adalah tugas utama TSPV karena baik perhatian dan kesadaran promotor merupakan tanggung jawab TSPV.

Desire, dalam hal ini follow up dilakukan berdasarkan dari kemampuan team dalam menghasilkan penjualan. Proses follow up ini pihak TSPV memegang peran sebagai komunikasi terpercaya oleh tim. Sebagai gudang jawaban dari segala sesuatu maslah inilah yang membuat sosok TSPV memiliki peran besar terhadap teamnya masingmasing. Kedekatan emosional ini juga dibangun dengan waktu yang cukup lama atau ada beberapa TSPV yang dulunya berasal dari promotor berprestasi dan menjadi leader kemudian memegang kembali tim promotor.

Action, proses ini adalah tahapan dimana orang mengambil tindakan untuk membeli barang yang dijual. Jadi proses AIDA bisa digambarkan sebagai proses: pengenalan produk — penciptaan ketertarikan terhadap produk mengakibatkan timbulnya hasrat untuk membeli produk — dan akhirnya pengambilan keputusan untuk membeli produk tersebut. Seperti dalam penjelasan sebelumnya bahwa ending dari sebuah sikap ini ialah bagaimana gerakan atau aksi yang dilakukan setelah mendapatkan materi dan pelatihan yang bersifat berkala ini.

Karena dalam prosesnya tim promotor akan menjalin hubungan dengan masyarahat luas. Seperti yang dijelaskan dalam buku komunikasi pemasaran menjelaskan bahwa hubungan masyarakat adalah berbagai program untuk mempromosikan dan untuk melindungi citra perusahaan atau masing-masing produknya.

Maka dari sumber tersebut diketahui bawah ada beberapa daya tarik yang menjadi gambaran hubungan masyarakat yang diperlukan oleh tim promotor. Menelaah dari proses AIDA yang dipaparkan dalam kegiatan follow up yang dilakukan oleh tim TSPV maka daya tarik hubungan masyarakat ialah :

1. Kredibilitas yang tinggi, Cerita dan penggambarannya mengenai beritanya lebih otentik dan dipercaya oleh konsumen dibandingkan dengan iklan biasa. Sehingga promotor menjadi sebuah sumber terpercaya

2. Kemampuan menangkap pembeli yang tidak dibidik sebelumnya, dalam hal ini ialah konsumen baru yang berhasil menjadi konsumen yang kemudian memilih dan menjadikan produk OPPO sebagai pilihannya. Hal ini lah yang dimaksud dalam proses follow up dan management kemampuan promotor yang berhasil berhenti dalam peningkatan penjualan di area Bengkulu

3. Dramatisasi, dalam hal ini bukan berarti promotor tidak mengatakan yang sesungguhnya atau mengatakan yang tidak sesuai kenyataan namun bagaimana promotor mampu memberikan penjelasan dengan cerita yang menghasilkan citra yang positif terhadap perusahaan dan produk yang menjadi sebuah produk fokus.

Meski dalam prakteknya bahwa produsen seringkali menggunakan hubungan masyarakat dengan perencanaan yang sedikit membuat konsumen seolah untung namun membohongi publik. Namun dalam dunia marketing hal ini tidak akan lama. Hal ini lah yang menjadi pedoman bahwa OPPO tidak memberikan pengajaran untuk menginformasikan hal terlalu berlebihan. Namun cukup 
memberikan bumbu (testimoni atau dramatisasi) yang sesuai dengan kebutuhan dan rekomendasi yang diinginkan oleh konsumen baik yang baru atau yang sudah lama.

\section{Persuasif Communication Magic}

Dalam NPL mendefinisikan (State of Persuassion ; Antonius Arif) mengatakan bahwa himpunan nilai tertentu dalam diri seseorang. Fisiologi, neurologi dan biokimia yang menimbulkan ekpresi perilaku dan pengalaman subyektif terhadap dunia. Peneliti melihat dalam area komunikasi persuasif memberikan sebuah hasil yang menentukan sikap seseorang.

Seperti dalam Metode Johari Window yang membagi area komunikasi kepemimpinan bisa menjadi 4 area.

Area 1, Bidang Terbuka, yang menunjukan bahwa kegiatan yang dilakukan secara disadari sepenuhnya oleh yang bersangkutan, juga oleh orang lain. Ini menggambarkan adanya komunikasi yang terbuka dalam hubungan atasan dan bawahan berorganisasi.

Area 2, Bidang Buta, yang menggambarkan bahwa seseorang bertingkah laku dimana orang mengetahui dari apa yang dia lakukan namun dirinya sendiri yang melakukan hal tersebut tidak sadar bahwa hal apa yang dilakukan sebenarnya.

Area 3, Bidang Tersembunyi, disadari sepenuhnya namun orang lain tidak dapat mengetahuinya. Ini berarti sikap tertutup agar apa yang dilakukan tidak diketahui oleh orang lain. Dan area terakhir yaitu

Area 4, Unknown Area, yang menggambarkan bahwa tingkah laku seseorang tidak disadari oleh dirinya sendiri dan tidak diketahui oleh orang lain.

Dalam gambaran ini maka sesungguhnya yang digunakan komunikasi persuasif tim TSPV ke tim promotor dalam meningkatkan kemampuan yang berujung kepada meningkatnya penjualan ialah Area 1. Hal ini membuat team TSPV dapat menemukan hal-hal yang menyulitkan atau dirasa oleh tim promotor.
Seperti keluhan tekanan dan target meski sesungguhnya segala sesuatu telah diatur oleh masing-masing TSPV area. Maksud area 1 disini adalah bentuk komunikasi yang dilakukan antara TSPV dan Promotor. Bukan dalam konteks yang lain, ini berdasarkan konteks yang disesuaikan dengan peningkatan kemampuan promotor. Namun dalam metode ini ada satu kondisi yang bisa saja membuat komunikasi ini berada pada Area 2. Dimana promotor melakukan sesuatu seolah itu dilakukan secara kesadaran dan dirinya sendiri tidak menyadarinya ialah Rasa kepemilikan terhadap brand dan perusahaan.

Sikap dan komunikasi internal yang dilakukan membuat promotor merasa memiliki kedekatan dan hubungan yang jauh lebih baik dibandingkan dengan yang lain kepada perusahaan. Sehingga hal inilah yang membuat mereka (promotor) tanpa sadar mengetahui bahwa rasa yang dimilikinya itu ialah sebuah bentuk strategi yang dilakukan dalam perusahaan. Namun jika menolak pun tidak bisa. Bentuk hasil komunikasi yang mengakibatkan penerima pesan tanpa disadari melakukan sikap yang diinginkan tanpa disuruh. Seperti melakukan live dan penjualan online yang dilakukan tanpa sebuah regulasi berubah menjadi kebiaaan yang kemudian dilakukan tanpa disadari dan tanpa dipaksa oleh pihak manapun.

Karena menurut Ellen Langer dalam buku Antonius Arif mengatakan bahwa pengaruh berhasil membujuk orang lain tetapi proses komunikasi yang kemudian menggunakan gambaran "karena" berefek lebih besar dalam mempersuasi. Dan semakin tinggi atau banyak yang masuk akal dalam berbicara akan menghasilkan tingkat evaluasi yang berhasil dan tinggi untuk sukses. Menurut Kevin Hogan menjelaskan bahwa ada 7 keajaiban dalam komunikasi internal atau persuasif yaitu :

1. Karena $x$ maka $y$ atau bolehkah $x$ karena $y$, Kata karena sangat berdampak besar pada sebuah kalimat yang diucapkan. Ini adalah hokum 
sebab dan akibat. Menurut penelitian "karena" menciptakan keberhasilan. Hal ini lah yang membuat promotor memiliki kemampuan FAQ dari penolakan atau complain user. Dan membangun kepercayaan ini team TSPV menjelaskan dengan analogi sehingga tim promotor memahaminya dengan benar.

2. Sekarang, kondisi bahwa TSPV menjelaskan bahwa promotor adalah orang yang terbaik dan menjelaskan segala sesuatu bahwa timnya adalah yang terbaik sekarang. Dan tidak ada waktu menunggu nanti

3. Imajinasi, adalah proses komunikasi dengan memberikan bayangan sikap dan hasil yang bisa saja terjadi jika promotor mendengarkan apa yang dikatakan oleh TSPV sehingga dalam hal ini. Promotor bersikap jauh lebih bisa membayangkan secara visual dan menanggapinya dengan jauh lebih baik. karena sikap yang memberikan bayangan ini bisa membuat promotor menganalisa visual dengan baik

4. Berucap Terima Kasih, kadang sebagai tim dengan garis koordinasi dengan TSPV ketika mereka melakukan hal yang baik maka berikan sebuah apresiasi dengan baik. tanpa memberikan hadiah namun dengan mengucapkan kata terima kasih sudah menjadi sebuah sikap hebat yang dirasa oleh promotor sangat membantu leadernya

5. Meminta sebuah izin permintaan, ini yang membedakan komunikasi internal dan bos. Dimana sebuah instruksi tidak disampaikan secara sembarangan. Sehingga nantinya tim tidak merasa terganggu jika ada permasalahan lagi nantinya yang mencakup ketentuan dari tim pimpinan lainnya

6. Menyebutkan Nama atau Panggilan, karena ketika dalam 1 managemen bahkan ada yang bisa lebih banyak jumlah promotornya yang mana mereka merasa sangat bahagia jika diketahui nama dan jadwal offnya dan masih banyak lagi

7. Kontrol, meski memiliki komunikasi internal dengan promotor namun TSPV tetap harus menjadi orang yang memegang kontrol dengan baik. Tujuannya adalah untuk bisa tetap memanage tim dengan sangat baik. Karena jika tidak bisa memegang kontrol maka akan ada masalah dalam hasil akhirnya nanti.

Ketujuh hal diatas diajarkan kepada promotor dan digunakan dalam komunikasi dengan team dan diketahui bahwa hal inilah yang bisa saja dianggap nantinya. Suara TSPV menjadi salah satu yang didengarkan oleh promotor sekaligus disegani oleh timnya masing-masing.

\section{Dampak Management Training/Tutor Terhadap Promotor}

Management Training adalah sebuah program yang dibuat oleh perusahaan ini secara pribadi untuk tim internal yang membuat kelas secara pribadi dan bersifat harian/mingguan dan juga bulanan. Hal ini dibuat langsung oleh OPPO untuk memastikan tim internal bisa menjadikan hal ini sebagai sebuah proses komunikasi internal. Hal-hal apa saja yang menjadi materi dalam training untuk promotor meliputi Produk, Komuikasi Penjualan, Layanan Garansi, Service Center dan beberapa hal lainnya dalam hal tanggung jawab seorang promotor di dalam toko. Dampak yang paling terlihat ialah :

1. Penjualan, promotor yang mendapatkan penjualan yang baik memiliki kemampuan yang tidak jauh dari ratarata maka dipastikan memiliki angka yang aman. Selain itu masa kerja promotor juga akan cukup lama karena mendapatkan level bintang kerja yang baik

2. Program, promotor akan mendapatkan banyak sekali program pusat sehingga membantu mereka mendapatkan prosedur lebih baik

3. Promotor Under, tidak langsung di hentikan kontrak melainkan di training 
ulang dan diberikan treatment yang berbeda sehingga promotor dapat mengetahui apakah memang potensi toko atau promotor yang tidak baik

Kondisi sekarang OPPO Big Bengkulu memiliki 240 orang promotor dengan jumlah leader per toko rata-rata adalah promotor dengan kemampuan lebih baik dibanding promotor lainnya. Dampak terbesar adalah salary yang didapatkan akan jauh lebih besar dengan insentif yang banyak. Selain itu mereka mendapatkan posisi sebagai leader team (jika dalam toko memiliki $>1$ promotor) sehingga memanage dan mengatur angka OPPO. Dalam hal ini team leader biasanya terbentuk sendrii setelah adanya Training Camp yang dilakukan MT (Management Trainer) yang dimanage oleh manager TSPV Bengkulu.

\section{PENUTUP}

\section{Kesimpulan}

Berdasarkan dengan penelitian yang dilakukan dan beberapa hal yang dibahas dalam penelitian ini maka dapat ditarik kesimpulan bahwa :

1. Proses komunikasi yang sangat efektif tidak hanya mampu merubah perspektif dan perilaku orang lain namun bisa mengubah sebuah sikap lainnya yang kemudian komunikasi tidak hanya datang dari timbal balik melainkan juga dari proses $\mathrm{A}$ ke $\mathrm{B}$ dan $\mathrm{B}$ bisa ke orang lainnya

2. Komunikasi bisa menjadi sebuah strategi pemasaran yang memberikan dampak besar terhadap sebuah perusahaan atau citra lainnya. Namun dalam hal ini komunikasi menjadi salah satu faktor lainnya yang kemudian membuat team pemasaran mampu memberikan kombinasi bahasa yang merubah keputusan bahkan kepercayaan user

3. Promotor adalah orang yang mempromosikan namun dalam hal ini managemen dan kontrol pengetahuan, kemampuan berbicara dan keberuntungan mempengaruhi satu sama lainnya sehingga perilaku marketing tidak hanya berdasarkan iklan dan budget branding yang tinggi saja

4. Implementasi dalam komunikasi diperlukan sosok atau tim yang fokus dalam membangun hal tersebut. Seperti halnya TSPV adalah tim yang fokus memikirkan apa dan bagaimana meningkatkan penjualan dari sisi sumber daya manusia dalam perusahaan tersebut

5. Metode dalam komunikasi organisasi baik dengan persuasif dan motivasi berpengaruh dalam hal ini sehingga membuat kumpulan dalam organisasi dapat bersaing ditengah pangsa pasar

Dalam penelitian ini juga pembaca bisa melihat bahwa tidak hanya sebuah iklan di televisi nasional yang bisa menjadi faktor besar. Namun juga proses komunikasi, komunikasi tidak hanya bisa mengubah perspektif melainkan tingkah laku dan hasil akhir.

\section{Saran}

Berdasarkan hasil penelitian yang diperoleh, penulis mengajukan beberapa saran yang diharapkan dapat menjadi bahan masukan bagi pihak-pihak yang berkepentingan dengan penelitian ini. Adapun saran-saran tersebut antara lain :

1. Penulis menyarankan kepada pihak OPPO untuk melakukan iklan mengenai produk-produk dengan membuat seperti training dan lain-lain. Hal ini dimaksudkan agar melalui iklan tersebut pengetahuan masyarakat mengenai OPPO dikalanhan tertentu.

2. Bagi kalangan promotor untuk tetap melakukan komunikasi yang baik dengan setiap konsumen

3. Membuat sebuah fanpage atau training konsumen mengenai kemampuan lainnya yang dimiliki oleh handphone OPPO. Karena proses intens seperti ini juga bisa membantu dalam membangun komunikasi secara berkala kepada tim dan user baik baru atau yang lama 
DAFTAR PUSTAKA

Arif, Antonius. 2012. The Billionaire Attitude :90 Hari Percepatan Sukses Melalui Mind-Logy. Jakarta, Titik Media (hlm 12-41 Bab I -Bab III, 128,)

Hogan, Kevin. 2004. The Psychology Of Persuasion : How To Persuade Other To Your Way Thinking. USA, Pelican Publishing Company . inc, (hlm 31)

Fandy Tjiptono. 2000. Strategi Pemasaran. Yogyakarta, Andi (h. 219)

Hartono, Hendry. 2012. Pengaruh Strategi Pemasaran Terhadap Peningkatan Penjualan Pada Perusahaan Dengan Menetapkan Alumni dan Mahasiswa Universitas Bina Nusantara Sebagai Objek Penelitian. Jakarta Barat (hlm : 883)

Haryatmoko, 2003. Etika Politik dan Kekuasaan. Jakarta, Penerbit Kompas

Ivana. 2016. Analisis Penerapan Strategi Promosi Dalam Upaya Meningkatkan Jumlah Nasabah KSPPS BMT Cabang Lampung. Semarang (hlm : 2)
Nicolay, Hingdranata. 2018. Selling Easily: Menjual dengan Mudah dan Cerdas. Jakarta (hlm : 36)

Nicolay, Hingdranata. 2018. Selling Easily: Menjual dengan Mudah dan Cerdas. Jakarta (hlm : 12)

Pace, R. Wayne, Philip C. Smith. 2006. Komunikasi Organisasi Strategi meningkatkan kinerja Perusahaan. Jakarta (hlm, 30, 150)

Onong, Prof Drs O. 2006. Teori Komunikasi . Jakarta (hlm :122)

Ronald, Hendrik. 2018. Menjual Barang Mahal Menjadi Murah dan Mudah. Jakarta ( hlm : 26)

Safitri, Ivana. 2016. Analisis Penerapan Strategi Promosi Dalam Upaya Meningkatkan Jumlah Nasabah KSPPS BMT Cabang Lampung. Semarang (hlm : 2)

Yusuf, Zainul Abidin. 2015. Manajemen Komunikasi (Filosofi, KOnsep dan Aplikasi ). Bandung, Pustaka Setia 